\title{
The Role of Proverbs in Extension Dissemination and Technology Transfer: A Case of Ethiopia
}

\author{
Mesfin Hailemariam ${ }^{1} \quad$ Mekedese Sheferaw $^{2} \quad$ Fikeremariam Yirgu $^{3}$ \\ 1.Ethiopian Institutes of Agricultural Research, Jimma Agricultural Research, Department of Field crop division, \\ 2.Ethiopian Institutes of Agricultural Research, Jimma Agricultural Research, Extension and communications \\ research divisions \\ Wolkite University, Department of Ethiopian language studies
}

\begin{abstract}
This paper examines the use of proverbs in extension and communications in Ethiopia. The purpose of this article is to show the influence proverbs in extension and technology transfer. In Ethiopia the use in the farming community of proverb to encourage or discourage the society, to influence the weak so that to be strong, to encourage the strong farmers and appreciate the industrious. This research aims to was to assess the role and implications of proverbs with regards of the agricultural extensions and communications in Ethiopia. The paper concludes indigenous Ethiopian proverbs are rich in conveying messages, rich in knowledge and. Hence, the use of proverbs in the farming society need to be further exploited.
\end{abstract}

Keywords: Proverb, Tradition, Extension, A metaphorical

DOI: $10.7176 / \mathrm{JBAH} / 9-21-01$

Publication date: November $30^{\text {th }} 2019$

\section{INTRODUCTION}

Ethiopia has 83 different languages with up to 200 different dialects spoken. According to Webster dictionary proverb is a short, well-known pithy saying, stating a general truth or piece of advice. Proverb is a very short and precise reflections of human knowledge wisdom of life. It generalizes the high extent of certain social experiences and finds its linguistics realizations in a quite popular metaphorical language (Conard,1975). It usually is very well known because of its popular use in colloquial language. Ethiopia is a nation of diverse society and mainly the people of stay in agriculture and diversity culture, religious and traditions. Proverb is a simple concrete traditional saying that express truth based on common sense or experience. Some proverbs exist in more than one language because people borrow them from languages and cultures similar to theirs ()

Proverbs is belonging to a very old literacy tradition of mankind. They disclose in a surprising precise manner a people's philosophy of life its ideas and concepts about the world, its self -consciousness. They reflect common human knowledge and experiences, perceptions, attributes etc.

Proverb is the wit of one and wisdom of money (). It's a short generally known sentence of the folk which amethapholical fixed and memorized from the which handed from generation to generation. ()

\section{Objectives}

\subsection{General Objectives}

* To promote the collection and research activities of oral literature in the farming community

* To identify how to preserve, document and disseminates the proverbs, and

* Identify the indigenous communication media that are often utilized by the rural dwellers in the state

\subsection{Specific Objectives}

The specific objectives intended

- To identify the role of proverbs in extension

- To examine the relative application of those proverbs and

- To know the level of usage in the time of the day.

\section{METHODOLOGY}

The study was descriptive methods. The researcher was collected the proverbs from the society grass roots labels viz., By asking from the elders, by referring the Amharic proverb books, and with personal commications with farmers and language teachers/lecturers. Beside this, the researchers tried to collected the proverbs which only have motivational, inspirational and optimistic to the societal change.

\section{A SHORT HISTORY OF PROVERB IN ETHIOPIAN HISTORY}

In most instances time and places of origin of a proverb is not, its author or creator is not remains unknown and due to the long age of proverbs and growing social contracts between people of a certain process of 
‘internalizations' of proverbs can be recognized.

\section{PROVERBS AND AGRICULTURAL EXTENSIONS AND COMINICATIONS}

The role of proverbs in the farming community has a reflects all spheres in life. It is mostly related to educated the people with inspirational and motivational ways. That means the farmers uses as a tool of identifying the weak, the innovator, adopter, non-adpoter or laggers in their areas.

So, the roles are

- Better understanding of farmers and experts, researchers and developmental agents.

- It has a power to mind set up prepare them for various circumstances

- Create commitment, motivation and,

- It facilitates exchange of experience, ideas, from farmer to farmer and farmers to researchers.

\section{FEATURES AND LIMITATIONS OF PROVERBS}

According to Richter, unpublished proverbs are unique features. These are:

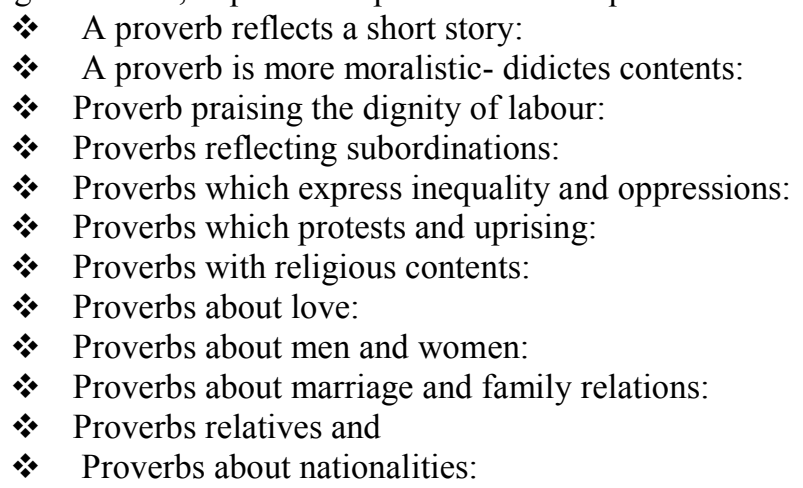

\section{RESULTS AND DISCUSSION}

It is well known that Ethiopia is a country with a very old literary traditions dating back to seventh century, if not before. This tradition is mainly based on the writing in Ge'ez, the classical language of Ethiopia which remained the medium of written communications until its substitutions by Amharic in the middle of the nineteenth century. The Aksumites developed Ge'ez, a unique script derived from the Sabean alphabet, and it is still used by the Ethiopian Orthodox Tewahedo Church today. Amharigna (Amharic) a and Tigrigna are the modern languages which are derived from Ge'ez. Amharic is the official national language of Ethiopia. In the Ethiopian context, some of the proverbs that related to the technology transfer and dissemination the is encouragements and motivation in the farmers are listed below in the table 1. Which is emphasis in the specific role of the proverbs in farming society. Table 1: Common proverbs and their meanings in terms of technology transfer

\begin{tabular}{|c|c|c|c|}
\hline № & Proverbs & $\begin{array}{l}\text { Amharic } \\
\text { equivalent }\end{array}$ & Meanings with examples \\
\hline 1. & $\begin{array}{l}\text { Regret, like a tail, comes at the } \\
\text { end }\end{array}$ & 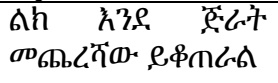 & $\begin{array}{l}\text { For the farmers that did't accept the } \\
\text { technology and missed the fortune }\end{array}$ \\
\hline 2. & $\begin{array}{l}\text { Cactus is bitter only to him who } \\
\text { tastes of it }\end{array}$ & 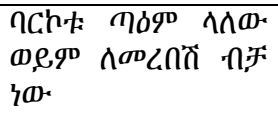 & $\begin{array}{l}\text { Before you judge something, you } \\
\text { need to know first. }\end{array}$ \\
\hline 3. & $\begin{array}{l}\text { A bird hanging between two } \\
\text { branches will get bitten on both } \\
\text { wings }\end{array}$ & 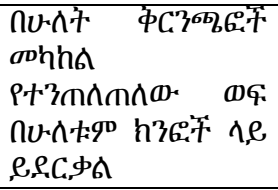 & $\begin{array}{l}\text { You can't use two things opposite } \\
\text { things simultaneously. i.e. you have to } \\
\text { choose the one better to be profitable. }\end{array}$ \\
\hline 4. & $\begin{array}{l}\text { Don't blame God for creating the } \\
\text { tiger -instead, thank him for not } \\
\text { giving it wings }\end{array}$ & 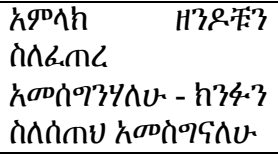 & $\begin{array}{l}\text { In life there may be worst scenario } \\
\text { than somebody experienced, so don't } \\
\text { give up }\end{array}$ \\
\hline 5. & $\begin{array}{l}\text { A good name is better than good } \\
\text { perfume }\end{array}$ & 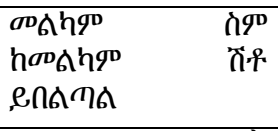 & $\begin{array}{l}\text { If you built your work in a best way, } \\
\text { you will have a chance to sustain it for } \\
\text { a long }\end{array}$ \\
\hline 6. & $\begin{array}{l}\text { She who does not yet know how } \\
\text { to walk cannot climb a ladder }\end{array}$ & 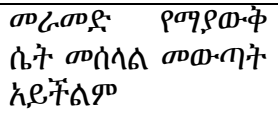 & $\begin{array}{l}\text { A man needs to try his best to do better } \\
\text { things. }\end{array}$ \\
\hline
\end{tabular}




\begin{tabular}{|c|c|c|c|c|}
\hline 7. & $\begin{array}{l}\text { The hyena has already gone by; } \\
\text { the dog barks }\end{array}$ & 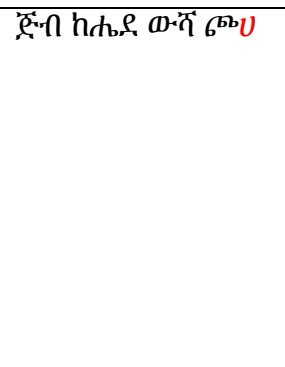 & & $\begin{array}{l}\text { Use the right opportunity, if you have } \\
\text { a chance of getting it. } \\
\text { If well protected behind the house } \\
\text { enclosure, dogs make an uproar at the } \\
\text { nocturnal passage of hyenas and alert } \\
\text { the masters; but if free and face to face } \\
\text { with them, they stay secure. In the } \\
\text { latter proverb the dog barks too late; } \\
\text { the danger is already passed. }\end{array}$ \\
\hline 8. & The coward sweats in water & 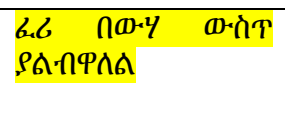 & $\%$ & $\begin{array}{l}\text { If somebody's have negative attitude } \\
\text { towards something, it will be difficult } \\
\text { to change. }\end{array}$ \\
\hline 9. & $\begin{array}{l}\text { Little by little, an egg will walk. } \\
\text { Or slowly, } \\
\text { slowly, even an egg will walk }\end{array}$ & 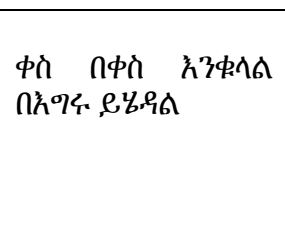 & $*$ & $\begin{array}{l}\text { The above proverb gives a good } \\
\text { lesson for the hopeless person. } \\
\text { Sometimes when a person fails in his } \\
\text { first try, he/she wants to give up on } \\
\text { that work and stay quit. At this time } \\
\text { the society says be patient is good. }\end{array}$ \\
\hline 10 & $\begin{array}{l}\text { Better to work hard than to be } \\
\text { bothered }\end{array}$ & 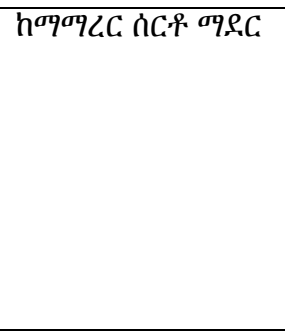 & $\$$ & $\begin{array}{l}\text { The other proverb which shows the } \\
\text { need of working hard is "Better to } \\
\text { work hard than to be bothered". This } \\
\text { proverb clearly shows the life of the } \\
\text { people who arguing with the } \\
\text { extension workers in adopting new } \\
\text { technologies they face on their way of } \\
\text { working. }\end{array}$ \\
\hline 11. & $\begin{array}{l}\text { The stand one is melt; the runner } \\
\text { one is } \\
\text { escape. }\end{array}$ & 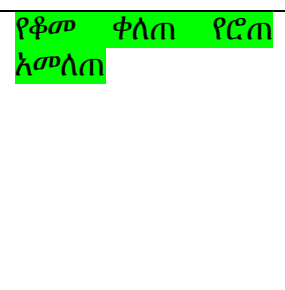 & 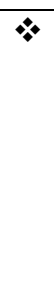 & $\begin{array}{l}\text { In Ethiopian society most of the time } \\
\text { people waiting things on the place } \\
\text { where they are. This is because they } \\
\text { may afraid to start new technology } \\
\text { that thing or they may wait those } \\
\text { things until to come towards them. At } \\
\text { that time, they lost so many things. }\end{array}$ \\
\hline 12. & Learning makes intelligent & 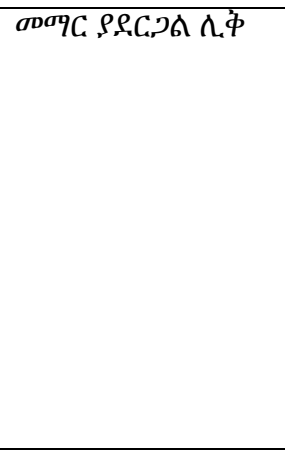 & $>$ & $\begin{array}{l}\text { The society believes that the only get } \\
\text { of wisdom is school, so they want } \\
\text { everybody to go for learning. At that } \\
\text { time the learners become intelligent } \\
\text { and they can be the persons who lead } \\
\text { and manage the country in every } \\
\text { aspect. } \\
\text { By thinking their final outcome, the } \\
\text { society motivates the youngsters to } \\
\text { go to school for getting knowledge } \\
\text { and to being intelligent. }\end{array}$ \\
\hline 13. & $\begin{array}{l}\text { Better to work hard than to be } \\
\text { bothered }\end{array}$ & 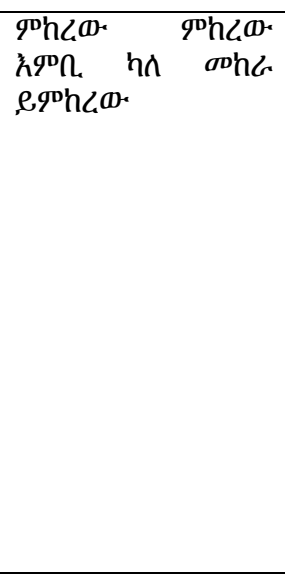 & & $\begin{array}{l}\text { The other proverb which shows the } \\
\text { need of working hard is "Better to } \\
\text { work hard than to be bothered". This } \\
\text { proverb clearly shows the life of the } \\
\text { people who arguing with the } \\
\text { government policies and some } \\
\text { problems they face on their way of } \\
\text { working. } \\
\text { Amhara society believes that losing } \\
\text { time by complain the system doesn't } \\
\text { bring anything. Rather they believe } \\
\text { that engaging in work helps and show } \\
\text { some direction for changing once life } \\
\text { and the whole society living standard. }\end{array}$ \\
\hline
\end{tabular}




\begin{tabular}{|c|c|c|c|}
\hline 14. & $\begin{array}{l}\text { You can lead a horse to water, but } \\
\text { you can't make him drink it }\end{array}$ & & $\begin{array}{l}\text { You can try to help someone by } \\
\text { giving good advice, but you can't } \\
\text { force them to accept it or follow it } \\
\text { "She tried to help her brother find a } \\
\text { job by improving his resume, but he } \\
\text { didn't do anything with it. I guess you } \\
\text { can lead a horse to water, but you } \\
\text { can't make him drink it." }\end{array}$ \\
\hline 15. & & 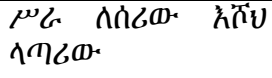 & e \\
\hline 16. & & 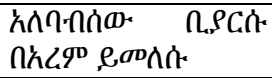 & $*$ \\
\hline 17. & & 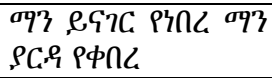 & $\%$ \\
\hline 18. & & 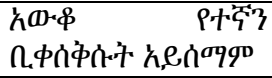 & $\%$ \\
\hline 19. & & 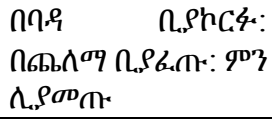 & $*$ \\
\hline
\end{tabular}

\section{SUMMARY AND CONCLUSIONS}

Proverbs in Ethiopia, which is common in aged, people that gives value to culture, and rural dwellers in peasants areas. It is becoming gradually phasing out, through time to time due to the exposures of exogenous media. In order to preserve this cultural heritage which has been handed down from generation to generation orally, great efforts are being made to collect, to write down, to translate and to publish these pieces Ethiopian proverbs previous time. But through time, these valuable proverbs didn't get an attention. This is due to luck of a strong institutions that capable of in resources and man power for the collections, use and research of this indigenous knowledge.

\section{RECOMMENDATIONS}

To use these valuable proverbs

- The agricultural research institutions and agricultural higher educations need to be set up for further study and use of this proverb,

- The generations must be focus on this indigenous knowledge than the foreign cultural move.

- $\quad$ To preserve this cultural heritage which has been handed from generation to generations orally.

\section{COMPETING INTERESTS}

Authors have declared that no competing interests exist.

\section{ACKNOWLEDGEMENT}

The authors would like to thanks that farmers involved in generating information in the paper writing process.

\section{REFERENCES}

1. Hussein, J.W., 2005. The social and ethno-cultural construction of masculinity and femininity in African proverbs.

2. Yonas Adamu Chernet. The Social Implications of Some Amharic Proverbs and Their Social Needs for Encouragement. International Journal of Literature and Arts. Vol. 3, No. 5, 2015, pp. 71-74. doi: 10.11648/j.ijla.20150305.11

3. Conard, (ed.) 1975-Kleines Worterbuch sprachwissenschaft-locher Termini, Leipzig.

4. http://www.ethiopiantreasures.co.uk/pages/language.htm 